\title{
KAJIAN SISTEM KINERJA KEUANGAN (OPERATING FINANCIAL SYSTEM) PADA ASURANSI SYARIAH DAN ASURANSI KONVENSIONAL DITINJAU DARI PERSPEKTIF HUKUM ISLAM
}

\author{
Jairin $^{1}$ \\ Sekolah Tinggi Ilmu Syari’ah AL-Ittihad Bima \\ bangrien@gmail.com
}

\begin{abstract}
Abstrak
Asuransi syariah merupakan usaha untuk saling melindungi dan tolong menolong diantara sejumlah orang melalui investasi dalam bentuk aset dan atau tabarru' yang memberikan pola pengembalian untuk menghadapi risiko/bahaya tertentu melalui akad yang sesuai dengan syariah. Pada hakikatnya, secara teoritis semangat yang terkandung dala sebuah lembaga asuransi tidak bisa dilepaskan dari semangat sosial dan saling tolong-menolong antara sesama manusia.

Asuransi sesuai dengan prinsip takafuli dalam syariah Islam, yaitu prinsip saling menanggung sesama muslim. Dalam rangka menjalankan usahanya, seseorang sering memerlukan penjaminan dari pihak lain melalui akad kafalah dalam Quran.
\end{abstract}

Kata Kunci: Asuransi Syariah, Asuransi Konvesional, Kajian Islam

\begin{abstract}
Shari'ah insurance is an effort to protect each other and help among a number of people through investments in the form of assets and / or tabarru 'which provides a pattern of return to face certain risks / dangers through a contract in accordance with sharia. In essence, theoretically the spirit contained in an insurance institution can not be separated from the social spirit and mutual assistance between human beings.

Insurance is in accordance with the principle of takafuli in Islamic sharia, which is the principle of mutual protection of fellow Muslims. In order to run a business, a person often requires guarantee from other parties through the kafalah agreement in the Quran.
\end{abstract}

Keywords:Sharia Assurance, Conventional Assurance, Islamic Studies.

\section{PENDAHULUAN}

Asuransi dalam bahasa Arab disebut at-ta'min yang berasal dari kata amanah yang berarti memberikan perlindungan, ketenangan, rasa aman serta bebas dari rasa sakit. Istilah men-ta'min-kan sesuatu berarti seseorang memberikan uang cicilan agar ia atau orang yang ditunjuk menjadi ahli warisnya mendapatkan ganti rugi atas hartanya yang hilang. 
Menurut ahli fikih kontemporer Wahbah Az-Zuhayli mendefinisikan asuransi berdasarkan pembagiannya. Ia membagi asuransi dalam dua bentuk yaitu at-ta'min at-ta'awuni dan at-ta'min bil-qist sabit. At-ta'min at-ta'awuni atau asuransi tolong menolong adalah kesepakatan sejumlah orang untuk membayar sejumlah uang sebagai ganti rugi ketika salah seorang diantara mereka mendapat kemudharatan. Sedangkan at-ta'min bil qist sabit atau asuransi dengan pembagian tetap adalah akad yang mewajibkan seseorang membayar sejumlah uang kepada asuransi yang terdiri atas beberapa pemegang saham dengan perjanjian apabila peserta mendapat kecelakaan ia diberi ganti rugi.

Sedangkan menurut Syakir Sula mengartikan takaful dalam pengertian muamalah adalah saling memikul risiko diantara sesama orang sehingga antara satu dengan yang lainnya menjadi penanggung atas risiko yang lainnya. Kemudian asuransi syariah didefinisikan sebagai usaha saling melindungi dan tolong menolong di antara sejumlah orang atau pihak melalui investasi dalam bentuk asset dan atau tabarru' memberikan pola pengembalian untuk menghadapi risiko tertentu melalui akad yang sesuai dengan syariah.

jikalau asuransi yang dibeli oleh masyarakan mengandung unsur syariahnya, seperti yang terkandung dalam Al-Quran yang artinya “... Dan tolong menolonglah kamu dalam (mengerjakan) kebaikan dan taqwa, dan jangan tolong menolong dalam berbuat dosa dan pelanggaran dan bertaqwalah kamu kepada Allah. Sesungguhnya Allah amat berat siksa-Nya."

Asuransi syariah menurut Dewan Syariah Nasional No.21/DSNMUI/X/2001 adalah usaha untuk saling melindungi dan tolong menolong diantara sejumlah orang melalui investasi dalam bentuk aset dan atau tabarru' yang memberikan pola pengembalian untuk menghadapi risiko/bahaya tertentu melalui akad yang sesuai dengan syariah. Pada hakikatnya, secara teoritis semangat yang terkandung dala sebuah lembaga asuransi tidak bisa dilepaskan dari semangat sosial dan saling tolong-menolong antara sesama manusia. dan yang terpenting adalah kesejahteraan ekonomi dengan kesempatan kerja penuh (full employment) dan tingkat pertumbuhan ekonomi yang tinggi, keadilan sosio-ekonomi dan distribusi pendapatan serta kekayaan yang wajar, stabilitas nilai uang, dan mobilisasi serta investasi tabungan untuk ekonomi yang mampu memberikan jaminan keuntungan (bagi hasil) kepada semua pihak yang terlibat (Kartiko, 2019). 
Di Indonesia yang merupakan negara dengan penduduk mayoritas beragama muslim, penerapan sistem asuransi dilakukan dengan ketentuan syariah. Sebagian besar perusahaanperusahaan asuransi di Indonesia sudah mulai mengeluarkan produk asuransi syariah. Salah satunya AJB Bumiputera 1912 Cabang Syariah Bima.

Menurut paham ekonomi, Asuransi merupakan suatu lembaga keuangan karena melalui asuransi dapat dihimpun dana besar, yang dapat digunakan untuk membiayai pembangunan, di samping bermanfaat bagi masyarakat yang berpartisipasi dalam bisnis asuransi, serta asuransi bertujuan memberikan perlindungan atau proteksi atas kerugian keuangan (financial loss), yang ditimbulkan oleh peristiwa yang tidak diduga sebelumnya (fortuitous event). Pada dasarnya perusahaan asuransi dalam kegiatannya, secara terbuka mengadakan penawaran atau menawarkan suatu perlindungan atau proteksi serta harapan pada masa yang akan datang kepada individu atau kelompok-kelompok dalam masyarakat atau institusi-institusi lain, atas kemungkinan menderita kerugian lebih lanjut karena terjadinya suatu peristiwa yang tidak tertentu atau belum pasti.

Risiko merupakan kemungkinan terjadinya suatu kerugian yang tidak diduga atau tidak diinginkan. Jadi merupakan ketidakpastian atau kemungkinan terjadinya sesuatu, yang apabila terjadi mengakibatkan kerugian. Manusia tidak dapat mengetahui apa yang akan ia perbuat esok hari, dan manusiapun tidak mengetahui di bumi mana ia meninggal dunia. Manusia setiap waktu dihadapkan dengan sederet bahaya yang mengancam jiwa, harta, kehormatan, agama, dan tanah airnya. Manusia juga dihadapkan dengan beragam risiko kecelakaan, mulai dari kecelakaan transportasi udara, kapal hingga angkutan darat dengan beragam jenisnya, ditambah kecelakaan kerja, kebakaran, perampokan, pencurian, sakit hingga kematian. Belum lagi ditambah dengan ancaman mental, seperti kegelisahan mental, ancaman globalisasi ekonomi, dan lain sebagainya.

Disamping itu, perusahaan asuransi juga memberikan jaminan atas terpenuhinya pendapatan seseorang, karena tempat dimana yang bersangkutan bekerja tetap terjamin kelangsungan kehidupannya. Dengan demikian dapat dikatakan kehadiran perusahaan asuransi dalam masyarakat itu jauh lebih bermanfaat bagi semua pihak dibandingkan dengan ketidakhadirannya.

Masih banyaknya pandangan dan keraguan masyarakat dalam menggunakan program Asuransi syariah, karena masyarakat masih terhegemoni dengan pandangan bahwa semua Asuransi baik Asuransi Syariah maupun Asuransi Konvensional itu sama cara kinerjanya, 
dengan demikian penulis sangat tertantang untuk memahami dan ingin tahu lebih dalam tentang kinerja dari baik Asuransi Syariah maupun Asuransi Konvensional, agar masyarakat bahkan penulis sendiri pun agar bisa memahami lebih dalam tentang perbedan baik secara kinerja maupun secara operasionalnya.

\section{ASURANSI SYARIAH}

Kata asuransi berasal dari bahasa Inggris, insurance yang menurut Echols dan Shadilly memaknai dengan (a) asuransi dan (b) jaminan.1 Menurut Muhammad Muslehuddin asuransi adalah persiapan yang dibuat oleh sekelompok orang yang masing-masing menghadapi kerugian kecil sebagai sesuatu sesuatu yang tidak dapat diduga. Apabila kerugian itu menimpa salah seorang dari mereka yang menjadi anggota perkumpulan tersebut, maka kerugian tersebut akan ditanggung bersama. (Sula, Asuransi Syariah (Life And General): Konsep Dan Sistem Operasional, 2004)

Secara umum, definisi asuransi adalah perjanjian antara penanggung (perusahaan asuransi) dengan tertanggung (peserta asuransi) yang dengan menerimapremi dari tertanggung, penanggung berjanji akan membayar sejumlahpertanggungan manakala tertanggung: Mengalami kerugian, kerusakan atau kehilangan atas barang/kepentingan yang diasuransikan karena peristiwa tidak pasti dan tanpa kesengajaan; dan b. Didasarkan hidup atau matinya seseorang.

Istilah asuransi, menurut pengertian ekonomi menunjukkan suatu aransemen ekonomi yang menghilangkan atau mengurangi akibat-akibat yang merugikan di masa akan datang kerena berbagai kemungkinan sejauh menyangkut kekayaan (vermoegen) seorang individu. Kemungkinan-kemungkinan tersebut harus bersifat tidak tetap (casual) bagi individu yang dipengaruhinya, sehingga setiap kejadian merupakan peristiwa yang tak terduga. Asuransi membagi rata segala akibat yang merugikan atas serangkaian kasus yang terancam oleh bahaya yang sama namun belum benar-benar terjadi.

Secara baku, definisi asuransi atau pertanggungan menurut Undang-Undang Republik Indonesia Nomor 2 Tahun 1992 Tentang Usaha Perasuransian adalah penjanjian antara dua pihak atau lebih, dengan mana pihak penganggung mengikatkan diri kepada tertanggung, dengan menerima premi asuransi, untuk memberikan penggantian kepada tertanggung karena kerugian, kerusakan atau kehilangan keuntungan yang diharapkan atau tanggung jawab hukum kepada pihak ketiga yang mungkin akan diderita tertanggung, yang timbul dari suatu peristiwa yang tidak pasti atau untuk memberikan suatu pembayaran yang didasarkan atas meninggal atau 
hidupnya seseorang yang dipertanggungkan. (Sula, Asuransi Syariah (Life And General): Konsep Dan Sistem Operasional, 2004)

Dalam menerjemahkan istilah asuransi ke dalam konteks asuransi Islam terdapat beberapa istilah, antara lain; At-Ta'min, Takaful dan Islamic Insurance. Istilah-istilah tersebut secara substansial tidak jauh berbeda dan mengandung makna yang sama, yakni pertanggungan (saling menanggung). (H. A. Djazuli, 2002)

Dalam bahasa Arab, asuransi disebut At-Ta'min. Penanggung disebut Mu'ammin sedangkan tertanggung disebut Mu'ammin Lahu atau Musta'min. At-Ta'min yang memiliki arti memberi perlindungan, ketenangan, rasa aman dan bebas dari rasa takut, sebagaiman firman Allah SWT, “Dan (Allah) mengamankan mereka dari ketakutan” (Quraisy : 4) Men-ta’min-kan sesuatu artinya adalah sesorang membayar/menyerahkan uang cicilan agar ia atau ahli warisnya mendapatkan sejumlah uang sebagaimana telah disepakati, atau mendapatkan ganti terhadap hartanya yang hilang. (Sula, Asuransi Syariah (Life And General): Konsep Dan Sistem Operasional, 2004)

Dalam Ensiklopedi Hukum Islam disebutkan bahwa asuransi (at-ta'min) adalah transaksi perjanjian antara dua belah pihak; pihak yang satu berkewajiban membayar iuran dan pihak lain berkewajiban memberikan jaminan sepenuhnya kepada pembayar iuran jika terjadi sesuatu yang menimpa pihak pertama sesuai dengan perjanjian yang dibuat.Menurut Undang-Undang No. 2 tahun 1992 tentang Usaha Perasuransian, Asuransi atau pertanggungan adalah perjanjian antara dua pihak atau lebih, yangmana pihak penanggung mengikat diri kepada tertanggung, dengan menerima premi asuransi, untuk memberikan penggantian kepada tertanggung karena kerugian, kerusakan atau kehilangan keuntungan yang diharapkan, atau tanggung jawab hukum kepada pihak ketiga yang mungkin ada diderita tertanggung, yang timbul dari suatu peristiwa yang tidak pasti, atau untuk memberikan suatu pembayaran yang didasarkan atas meninggal atau hidupnya seseorang yang dipertanggungkan. (Sastrawidjaja, 1997)

Berdasarkan Fatwa Dewan Syariah Nasional No.21/DSNMUI/X/2001, Asuransi Syariah (Ta'min, Takaful, Tadhamun) adalah usaha saling melindungi dan tolong menolong diantara sejumlah orang atau pihak melalui investasi dalam bentuk aset dan atau tabarru' memberikan pola pengembalian untuk menghadapi risiko tertentu melalui akad (perikatan) yang sesuai dengan syariah.

Dalam Kitab Undang-Undang Dagang (KUHD) pasal 246 dijelaskan bahwa yang dimaksud asuransi atau pertanggungan adalah "Suatu perjanjian, dengan mana seorang 
penanggung mengikat diri kepada seorang tertanggung, dengan menerima suatu premi, untuk memberikan penggantian kepadanya, kerena suatu kerugian, kerusakan, atau kehilangan keuntungan yang diharapkan yang mungkin akan dideritanya, kerena suatu peristiwa tak tertentu. Tujuan Asuransi adalah untuk mengadakan persiapan dalam menghadapi kemungkinan kesulitan yang dihadapi oleh manusia dalam kehidupan.

Pengertian asuransi sesuai dengan prinsip takafuli dalam syariah Islam, yaitu prinsip saling menanggung sesama muslim. Bahwa dalam rangka menjalankan usahanya, seseorang sering memerlukan penjaminan dari pihak lain melalui akad kafalah dalam Quran, kafalah dijelaskan sebagai berikut:

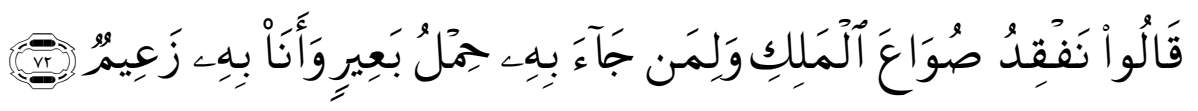

"Penyeru-penyeru itu berkata: "Kami kehilangan piala Raja, dan siapa yang dapat mengembalikannya akan memperoleh bahan makanan (seberat) beban unta, dan aku menjamin terhadapnya." (QS. Yusuf [12] : 72)

Dengan kata lain, Asuransi syariah adalah suatu pengaturan pengelolaan risiko yang memenuhi ketentuan syariah, tolong-menolong secara mutual yang melibatkan peserta dan operator. Syariah berasal dari ketentuan-ketentuan di dalam Quran (firman Allah yang disampaikan kepada Nabi Muhammad saw.) dan As-Sunnah (teladan dari kehidupan Nabi Muhammad SAW). (Iqbal, 2008)

Pada hakikatnya asuransi ialah suatu kemauan untuk menetapkan kerugian-kerugian kecil (sedikit) yang sudah pasti sebagai pengganti (substitusi) kerugian-kerugian besar yang belum pasti. (Amrin, Asuransi Syari’ah, 2006) Dilihat dari berbagai sudut pandang seperti segi ekonomi, bisnis, hukum dan sosial menjelaskan bahwa pengertian asuransi konvensional adalah pemindahan atau pengalihan risiko dari tertanggung kepada penanggung atau istilahnya adalah transfer risk. (Amrin, Asuransi Syari’ah, 2006)

Hal ini berbeda dengan asuransi syariah menurut DSN-MUI, risiko yang akan terjadi ditanggung bersama atas dasar ta'awun, yakni dengan menggunakan konsep saling berbagi risiko atau istilahnya adalah sharing of risk.

Letak perbedaan antara asuransi syariah dan asuransi konvensional adalah pada bagaimana risiko itu dikelola dan ditanggung, dan bagaimana dana asuransi syariah dikelola. Perbedaan lebih jauh adalah pada hubungan antara operator (pada asuransi konvensional istilah yang digunakan: Tertanggung). 


\section{ASURANSI KONVENSIONAL}

Pada hakikatnya asuransi ialah suatu kemauan untuk menetapkan kerugian-kerugian kecil (sedikit) yang sudah pasti sebagai pengganti (substitusi) kerugian-kerugian besar yang belum pasti. (Amrin, Asuransi Syari’ah, 2006) Dilihat dari berbagai sudut pandang seperti segi ekonomi, bisnis, hukum dan sosial menjelaskan bahwa pengertian asuransi konvensional adalah pemindahan atau pengalihan risiko dari tertanggung kepada penanggung atau istilahnya adalah transfer risk.

Dalam asuransi konvensional, asuransi adalah sebuah mekanisme perpindahan risiko yang oleh suatu organisasi dapat diubah dari tidak pasti menjadi pasti. Ketidakpastian mencakup faktor-faktor antara lain, apakah kerugian akan muncul, kapan terjadinya, dan seberapa besar dampaknya dan berapa kali kemungkinannya terjadi dalam satu tahun. Asuransi memberikan peluang untuk menukar kerugian yang tidak pasti ini menjadi suatu kerugian yang pasti yakni premi asuransi. Suatu organisasi akan setuju untuk membayar premi tetap dan sebagai gantinya perusahaan asuransi setuju untuk menutup semua kerugian yang akan terjadi yang termasuk dalam ketentuan-ketentuan polis.

Pertukaran kerugian tidak pasti dengan kerugian-pasti, seperti yang diterapkan dalam asuransi konvensional masuk dalam ruang lingkup pengertian gharar dan tidak diperbolehkan dalam Islam. Maka dalam konsep asuransi syariah, tidak ada perpindahan risiko dari para peserta kepada operator asuransi syariah. Risiko dibagi di antara para peserta dalam skema jaminan mutual atau skema asuransi syariah. Operator asuransi syariah hanya sebagai wakeel (agen) untuk membuat skema tersebut bekerja. Sudah menjadi bagian dari peran operator untuk memastikan seseorang yang ditimpa kemalangan sehingga mengalami kerugian bisa mendapatkan kompensasi yang layak. (Basryin, 2001).

\section{Sistem Kinerja Operating Financial System Asuransi Syariah dan Konvensional}

Hal ini berbeda dengan asuransi syariah menurut DSN-MUI, risiko yang akan terjadi ditanggung bersama atas dasar ta'awun, yakni dengan menggunakan konsep saling berbagi risiko atau istilahnya adalah sharing of risk. 
Letak perbedaan antara asuransi syariah dan asuransi konvensional adalah pada bagaimana risiko itu dikelola dan ditanggung, dan bagaimana dana asuransi syariah dikelola. (Salim, 2007). Perbedaan lebih jauh adalah pada hubungan antara operator (pada asuransi konvensional istilah yang digunakan: Tertanggung).

Dalam asuransi konvensional, asuransi adalah sebuah mekanisme perpindahan risiko yang oleh suatu organisasi dapat diubah dari tidak pasti menjadi pasti. Ketidakpastian mencakup faktor-faktor antara lain, apakah kerugian akan muncul, kapan terjadinya, dan seberapa besar dampaknya dan berapa kali kemungkinannya terjadi dalam satu tahun. Asuransi memberikan peluang untuk menukar kerugian yang tidak pasti ini menjadi suatu kerugian yang pasti yakni premi asuransi. Suatu organisasi akan setuju untuk membayar premi tetap dan sebagai gantinya perusahaan asuransi setuju untuk menutup semua kerugian yang akan terjadi yang termasuk dalam ketentuan-ketentuan polis.

Pertukaran kerugian tidak pasti dengan kerugian-pasti, seperti yang diterapkan dalam asuransi konvensional masuk dalam ruang lingkup pengertian gharar dan tidak diperbolehkan dalam Islam. Maka dalam konsep asuransi syariah, tidak ada perpindahan risiko dari para peserta kepada operator asuransi syariah. Risiko dibagi di antara para peserta dalam skema jaminan mutual atau skema asuransi syariah. Operator asuransi syariah hanya sebagai wakeel (agen) untuk membuat skema tersebut bekerja. Sudah menjadi bagian dari peran operator untuk memastikan seseorang yang ditimpa kemalangan sehingga mengalami kerugian bisa mendapatkan kompensasi yang layak. (Amrin, Asuransi Syari’ah, 2006)

Dan perbedaan mendasar yang lainnya adalah asuransi syariah bebas dari unsur gharar, maysir dan riba. Apa itu gharar, maysir dan riba? Gharar itu sesuatu yang tidak jelas atau ketidakpastian, maysir itu perjudian dan riba itu bunga yang saat ini kita kenal. Yang di dalam Islam ketiga unsur itu dilarang dan diharamkan. Lebih jelasnya berikut perbedaan di antara keduanya : a) Prinsip akad asuransi syariah adalah takafuli (tolong-menolong). Dimana nasabah yang satu menolong nasabah lain yang tengah mengalami kesulitan. Sedangkan akad asuransi konvensional bersifat tadabuli (jual-beli antara nasabah dengan perusahaan). Dan Dana yang terkumpul dari nasabah perusahaan asuransi syariah, (premi) diinvestasikan berdasarkan syariah dengan sistem bagi hasil (mudharabah). Sedangkan pada asuransi konvensional, investasi dana dilakukan pada sembarang sektor dengan sistem bunga; b) Premi yang terkumpul diperlakukan tetap sebagai dana milik nasabah. Perusahaan hanya sebagai pemegang amanah untuk 
mengelolanya. Sedangkan pada asuransi konvensional, premi menjadi milik perusahaan dan perusahaanlah yang memiliki otoritas penuh untuk menetapkan kebijakan pengelolaan dana tersebut. c) Premi yang terkumpul diperlakukan tetap sebagai dana milik nasabah. Perusahaan hanya sebagai pemegang amanah untuk mengelolanya. Sedangkan pada asuransi konvensional, premi menjadi milik perusahaan dan perusahaanlah yang memiliki otoritas penuh untuk menetapkan kebijakan pengelolaan dana tersebut; d) Bila ada peserta yang terkena musibah, untuk pembayaran klaim nasabah dana diambilkan dari rekening tabarru (dana sosial) seluruh peserta yang sudah diikhlaskan untuk keperluan tolong-menolong. Sedangkan dalam asuransi konvensional, dana pembayaran klaim diambil dari rekening milik perusahaan; e) Keuntungan investasi dibagi dua antara nasabah selaku pemilik dana dengan perusahaan selaku pengelola, dengan prinsip bagi hasil. Sedangkan dalam asuransi konvensional, keuntungan sepenuhnya menjadi milik perusahaan. Jika tak ada klaim, nasabah tak memperoleh apa-apa. Adanya Dewan Pengawas Syariah dalam perusahaan asuransi syariah yang merupakan suatu keharusan. Dewan ini berperan dalam mengawasi manajemen, produk serta kebijakan investasi supaya senantiasa sejalan dengan syariat Islam. Adapun dalam asuransi konvensional, maka hal itu tidak mendapat perhatian; f) Kemungkinan adanya dana yang hangus. Pada asuransi syariah tidak mengenal adanya dana yang hangus meskipun peserta asuransi menyatakan akan mengundurkan diri karena sesuatu dan lain hal. Dana yang telah disetorkan tetap dapat diambil kecuali dana yang sejak awal telah diikhlaskan masuk ke dalam rekening tabaru' (dana kebajikan). Sedangkan pada asuransi konvensional dikenal adanya dana yang hangus jika peserta tidak dapat melanjutkan pembayaran premi dan ingin mengundurkan diri sebelum masa jatuh tempo (reserving period). (Iqbal, 2008)

\section{Perbedaan Operating Financial System Asuransi Konvensional dan Asuransi Syariah}

Asuransi memiliki perbedaan baik pada asuransi Konvensional maupun pada Asuransi Syariah, untuk tidak membias kemana, dibawah ini, beberapa perbedaan antara Asuransi Konvensional maupun Asuransi Syariah, yang antara lain:

\begin{tabular}{|c|c|c|c|}
\hline No & Prinsip Asuransi & Konvensional & Asuransi Syariah \\
\hline 1 & Konsep & \begin{tabular}{lrr}
\multicolumn{3}{l}{ Perjanjian antara dua pihak atau } \\
lebih, dimana pihak penanggung \\
mengikatkan diri $r$ kepada \\
tertanggung dengan & menerima \\
premi asuransi, & untuk
\end{tabular} & $\begin{array}{l}\text { Sekumpulan orang yang saling membantu, } \\
\text { saling menjamin dan bekerja sama dengan } \\
\text { cara masing-masing mengeluarkan dana } \\
\text { Tabarru. }\end{array}$ \\
\hline
\end{tabular}




\begin{tabular}{|c|c|c|c|}
\hline & & $\begin{array}{l}\text { memberikan pergantian kepada } \\
\text { Tertanggung }\end{array}$ & \\
\hline 2 & Asal - Usul & $\begin{array}{l}\text { Dari masyarakat Babilonia 4000- } \\
3000 \text { SM yang dikenal dengan } \\
\text { perjanjian Hammurabi. Dan tahun } \\
1668 \mathrm{M} \text { di Coffe House London } \\
\text { berdirilah Lloyd of London } \\
\text { sebagai dikal bakal asuransi } \\
\text { konvensional }\end{array}$ & $\begin{array}{l}\text { Dari al- Aqilah, kebiasaan suku Arab jauh } \\
\text { sebelum Islam datang. Kemudian oleh } \\
\text { Rasulullah menjadi hukum Islam. Bahkan } \\
\text { telah tertuang dalam konstitusi pertama di } \\
\text { dunia (Konstitusi Madinah) yang dibuat } \\
\text { langsung oleh Rasulullah }\end{array}$ \\
\hline 3 & Sumber hukum & $\begin{array}{l}\text { Bersumber dari fikiran manusia } \\
\text { dan kebudayaan.Berdasarkan } \\
\text { hukum positif, hukum alami dan } \\
\text { contoh sebelumnya }\end{array}$ & $\begin{array}{l}\text { Bersumber dari wahyu Ilahi (Quran), } \\
\text { Sunnah Nabi, Fatwa Sahabat, Ijma', Qiyas, } \\
\text { Istihsan, 'Urf "tradisi" dan Mashlahah } \\
\text { Mursalah }\end{array}$ \\
\hline 4 & $\begin{array}{l}\text { Magrib } \\
\text { (Maisir,Gharar, } \\
\text { Riba) }\end{array}$ & $\begin{array}{l}\text { Tidak selaras dengan } \text { Syariah } \\
\text { Islam karena adanya Maisir, } \\
\text { Gharar dan Riba. Hal yang } \\
\text { diharamkan dalam muamalat }\end{array}$ & $\begin{array}{l}\text { Bersih dari adanya praktik Maisir, Gharar } \\
\text { dan Riba }\end{array}$ \\
\hline 5 & $\begin{array}{lr}\text { DPS } & \text { (Dewan } \\
\text { Pengawas } \\
\begin{array}{l}\text { Syariah) } \\
\text { ada }\end{array}\end{array}$ & $\begin{array}{l}\text { Sehingga dalam praktiknya } \\
\text { bertentangan dengan kaidah-kidah } \\
\text { Syara' }\end{array}$ & $\begin{array}{l}\text { Ada, yang berfungsi untuk mengawasi } \\
\text { pelaksanaan operasional perusahaan agar } \\
\text { terbebas dari praktik-praktik muamalat } \\
\text { yang bertentangan dengan prinsip-prinsip } \\
\text { syariah }\end{array}$ \\
\hline 6 & Akad & $\begin{array}{l}\text { Akad Jual-beli } \quad \text { (akad } \\
\text { mu'awadhah,akad idz'aan, akad } \\
\text { gharra dan akad mulzim) }\end{array}$ & $\begin{array}{l}\text { Akad Tabarru' dan akad Tijarah } \\
\text { (Mudharabah, wakalah, wadiah, syirkah } \\
\text { dan sebagainya) }\end{array}$ \\
\hline 7 & $\begin{array}{l}\text { Jaminan/Risk } \\
\text { (risiko) }\end{array}$ & $\begin{array}{l}\text { Transfer of Risk, dimana terjadi } \\
\text { transfer risiko dari tertanggung } \\
\text { kepada penanggung }\end{array}$ & $\begin{array}{l}\text { Sharing of Risk, diman terjadi proses } \\
\text { saling menanggung antara satu peserta } \\
\text { dengan peserta lainnya (ta'awun) }\end{array}$ \\
\hline 8 & Pengelolaan Dana & $\begin{array}{l}\text { Tidakada pemisahan dana, yang } \\
\text { berakibat pada terjadinya dana } \\
\text { hangus (untuk produk saving life) } \\
\text { dan dana peserta, sehingga } \\
\text { tidak mengenal istilah dana } \\
\text { hangus. Sedangkan untuk term } \\
\text { insurance (life) dan general } \\
\text { insurance semuanya bersifat } \\
\text { tabarru' }\end{array}$ & $\begin{array}{l}\text { Pada produk-produk saving (life) terjadi } \\
\text { pemisahan dana yaitu dana Tabarru' } \\
\text { 'derma' }\end{array}$ \\
\hline 9 & Investasi & $\begin{array}{l}\text { Bebas melakukan investasi dalam } \\
\text { batas-batas ketenuan undang- } \\
\text { undang, dan tidak terbatasi oleh } \\
\text { halal-haramnya obyek atau sistem } \\
\text { investasi yang digunakan }\end{array}$ & $\begin{array}{l}\text { Dapat melakukan investasi sesuai dengan } \\
\text { ketentuan perundang-undangan sepanjang } \\
\text { tidak bertentangan dengan prinsip Syariat } \\
\text { Islam. Bebas dari riba dan tempattempat } \\
\text { investasi yang terlarang }\end{array}$ \\
\hline
\end{tabular}




\begin{tabular}{|c|c|c|c|}
\hline 10 & $\begin{array}{l}\text { Kepemilikan } \\
\text { Dana }\end{array}$ & 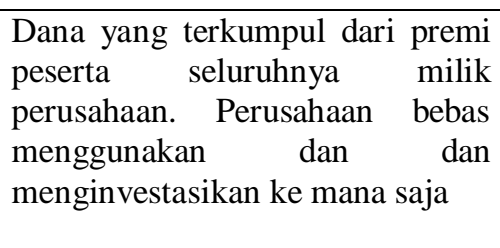 & $\begin{array}{l}\text { Dana yang terkumpul dari peserta dalam } \\
\text { bentuk iuran atau kontribusi, merupakan } \\
\text { milik peserta (shahibul mal). Asuransi } \\
\text { syariah hanya sebagi pemegang amanat } \\
\text { (mudharib) dalam mengelola dan tersebut }\end{array}$ \\
\hline 11 & Unsur Premi & $\begin{array}{l}\text { Unsur premi terdiri dari tabel } \\
\text { mortalita (Mortalitiy Tabels) } \\
\text { Bunga (Interest) biaya-biaya } \\
\text { asuransi (cost of Insurance) }\end{array}$ & $\begin{array}{l}\text { Iuran atau kontribusi terdiri dari unsur } \\
\text { Tabaru' dan tabungan. Tabarru' juga } \\
\text { dihitung dari tabel Mortalita, tetapi tanpa } \\
\text { perhitungan bunga teknik }\end{array}$ \\
\hline 12 & Loading & $\begin{array}{l}\text { Loading pada asuransi } \\
\text { konvensional cukup besar } \\
\text { terutama diperuntukkan untuk } \\
\text { komisi agen, bisa menyerap premi } \\
\text { tahun pertama dan kedua. Karena } \\
\text { itu nilai tunai pada tahun } \\
\text { pertama dan kedua biasanya } \\
\text { belum ada (masih hangus) }\end{array}$ & $\begin{array}{l}\text { Pada sebagian asuransi syariah loading } \\
\text { komisi agen) tidak dibebankan pada } \\
\text { peserta tetapi dari dana pemegang saham. } \\
\text { Namun sebagian yang lainnya } \\
\text { mengambilkan dari } 20-30 \text { persen saja dari } \\
\text { premi tahun pertama. Dengan demikian, } \\
\text { nilai tunai tahun pertama sudah terbentuk }\end{array}$ \\
\hline 13 & $\begin{array}{l}\text { Sumber } \\
\text { Pembayaran } \\
\text { Klaim }\end{array}$ & $\begin{array}{l}\text { Sumber biaya klaim adalah dari } \\
\text { rekening perusahaan, sebagai } \\
\text { konsekuensi penanggung terhadap } \\
\text { tertanggung. Murni bisnis dan } \\
\text { tidak ada nuansa spiritual }\end{array}$ & $\begin{array}{l}\text { Sumber pembiayaan klaim diperoleh dari } \\
\text { rekening Tabarru', yaitu peserta saling } \\
\text { menanggung. Jika salah satu peserta } \\
\text { mendapat musibah, maka peserta lainnya } \\
\text { ikut menanggung risiko secara bersama- } \\
\text { sama }\end{array}$ \\
\hline 14 & $\begin{array}{l}\text { Sistem Akuntansi } \\
\text { Menganut konsep } \\
\text { akuntansi }\end{array}$ & $\begin{array}{l}\text { accrual basis, yaitu proses } \\
\text { akuntsni yang mengakui } \\
\text { terjadinya peristiwa atau } \\
\text { kejadian non-kas yang baru } \\
\text { akan diterima dalam waktu } \\
\text { yang akan datang }\end{array}$ & $\begin{array}{l}\text { Menganut konsep akuntansi cash basis, } \\
\text { mengakui apa yang benar-benar telah ada. } \\
\text { Sedangkan accrual basis dianggap } \\
\text { bertentangan dengan syariah karena } \\
\text { mengakui adanya pendapatan harta, beban, } \\
\text { atau utang yang akan terjadi dimasa yang } \\
\text { akan datang. Sementara apakah itu benar- } \\
\text { nemar terjadi hanya Allah yang tahu. }\end{array}$ \\
\hline 15 & $\begin{array}{l}\text { Keuntungan } \\
\text { (profit) }\end{array}$ & $\begin{array}{l}\text { Keuntungan yang diperoleh } \\
\text { dari surplus } \\
\text { underwriting, komisi } \\
\text { reasuransi dan hasil investasi } \\
\text { seluruhnya adala keuntungan }\end{array}$ & $\begin{array}{l}\text { Profit yang diperoleh dari surplus } \\
\text { underwriting,komis reasuransi dan hasil } \\
\text { investasi bukan seluruhnya menjadi milik } \\
\text { perusahaan, tetapi dilakukan bagi hasil } \\
\text { (mudharabah) dengan peserta }\end{array}$ \\
\hline
\end{tabular}

KETENTUAN-KETENTUAN POKOK PERJANJIAN ASURANSI SYARIAH 


\section{Akad Tabaru'}

Kejelasan akad dalam praktik muamalah merupakan prinsip, karena akan menentukan sah atau tidaknya secara syariah. Demikian halnya dalam asuransi, akad antara perusahaan dengan peserta harus jelas. Akad-nya dapat berupa jual beli (tabduli) atau tolong menolong (takafuli). (Ma’ruf Abdul Jalil, 2008)

Beberapa fatwa DSN-MUI yang memuat tentang akad dalam asuransi syariah diantaranya tentang mudharabah, seperti Fatwa No.1/DSN-MUI/IV/2000 tentang Giro, Fatwa No. 2/DSNMUI/IV/2000 tentang Tabungan, Fatwa No.3/DSN-MUI/IV/2000 tentang Deposito, Fatwa No. 7/DSN-MUI/IV/2000 tentang Pembiayaan Mudharabah dan Fatwa No. 21/DSN-MUI/X/2001 tentang Pedoman Umum Asuransi Syariah khususnya mengenai akad Tijarah (Mudharabah). Selanjutnya memuat akad Mudharabah Musyarakah, yaitu salah satu bentuk akad Mudharabah di mana pengelola (mudharib) turut menyertakan modalnya dalam kerjasama investasi; diperlukan karena mengandung unsur kemudahan dalam pengelolaannya serta dapat memberikan manfaat yang lebih besar bagi para pihak.

Tabaru

Tabarru' berasal dari kata tabarraa yatabarraa tabarrauan, yang artinya sumbangan atau derma. Orang menyumbang disebut mutabarri (dermawan). Tabarru’ bermaksud memberikan dana kebijakan secara ikhlas untuk tujuan saling membantu antara peserta Asuransi, ketika diantara mereka ada yang terkena musibah. Dana tabarru’ disimpan dalam rekening khusus. (Sudarsono, 2004) Berbeda dengan asuransi konvensional yang menerapkan dana hangus, karena semua dana derma peserta (premi) dimasukkan dalam rekening perusahaan. Jadi bila ada musibah yang menimpa peserta (klaim) maka akan mengambil dana pertanggungan dari rekening perusahaan. Begitu pula sebaliknya, jika peserta tidak mengalami kerugian atau musibah, maka dana derma tersebut menjadi milik perusahaan.

Adapun mengenai landasan hukum tabaru’ ini berdasarkan DSN-MUI bahwa fatwa No. 21/DSN-MUI/X/2001 tentang Pedoman Umum Asuransi Syariah dinilai sifatnya masih sangat umum sehingga dilengkapi dengan fatwa yang lebih rinci fatwaNo. 53/DSNMUI/III/2006.

\section{Risiko}


Risiko dalam Kamus Umum Bahasa Indonesia adalah kemungkinan, bahaya kerugian akibat yang kurang menyenangkan (dari suatu perbuatan, usaha dan sebagainya). Risiko adalah ketidaktentuan atau uncertainty yang mungkin melahirkan kerugian (loss). Unsur ketidaktentuan ini bisa mendatangkan kerugian dalam asuransi. Dalam praktiknya risiko yang timbul dari setiap usaha pertanggungan asuransi adalah sebagai berikut: a) Risiko murni, artinya ketidakpastian terjadinya sesuatu kerugian atau dengan kata lain hanya ada peluang merugi dan bukan suatu peluang keuntungan, contoh rumah mungkin akan terbakar; b) Risiko spekulatif, artinya risiko dengan terjadinya dua kemungkinan yaitu peluang untuk mengalami kerugian keuangan atau memperoleh keuntungan; c) Risiko individu, yang terbagi menjadi tiga macam; pertama, risiko pribadi, yaitu risiko kemampuan seseorang untuk memperoleh keuntungan, akibat sesuatu hal seperti sakit, kehilangan pekerjaan atau sakit. Kedua, risiko harta, yaitu risiko kehilangan harta seperti, dicuri, hilang, rusak yang mengakibatkan kerugian keuangan. Ketiga, risiko tanggung gugat, yaitu risiko yang disebabkan apabila kita menanggung kerugian seseorang dan kita harus membayarnya.

\section{Polis}

Dalam kamus, polis asuransi diartikan sebagai kontrak tertulis antara tertanggung dan penanggung mengenai pengalihan risiko dengan syarat tertentu (insurance policy) yakni bukti tertulis atau surat perjanjian antara pihak-pihak yang mengadakan perjanjian asuransi. Polis asuransi secara umum adalah kontrak yang diikat secara hukum dimana pemegang polis (atau pemilik) membayar sejumlah premi sebagai ganti pembayaran yang akan dilakukan oleh perusahaan asuransi bergantung pada peristiwa yang akan terjadi di masa depan.

\section{Underwriting}

Menurut asuransi kerugian, underwriting adalah proses seleksi untuk menetapkan jenis penawaran risiko yang harus diterima, bila diakseptasi, rate, syarat, dan kondisinya harus dapat ditentukan. Berbeda menurut asuransi jiwa, underwriting adalah proses penaksiran mortalitas (angka kematian) atau morbiditas (angka kesakitan) calon tertanggung untuk menetapkan apakah akan menerima atau menolak calon peserta dan menetapkan klasifikasi peserta. 
Dalam menentukan premi didasarkan atas kesepakatan bersama mengenai pelimpahan kekuasaan oleh satu pihak kepada pihak lain dalam hal-hal yang boleh diwakilkan melalui proses underwriting dari perusahaan asuransi. Dalam fatwa DSN-MUI No.10/DSNMUI/2000 tentang Wakalah dan fatwa No. 21/DSN-MUI/X/2001 tentang Pedoman Umum Asuransi Syariah dinilai sifatnya masih sangat umum sehingga perlu dilengkapi dengan fatwa yang lebih rinci. Salah satu fatwa yang diperlukan adalah fatwa tentang Wakalah bil Ujrah untuk asuransi, yaitu salah satu bentuk akad Wakalah dimana peserta memberikan kuasa kepada perusahaan asuransi dengan imbalan pemberian ujrah (fee).

\section{Premi atau Kontribusi}

Premi atau Kontribusi merupakan pembayaran sejumlah uang yang dilakukan pihak tertanggung kepada penanggung untuk mengganti suatu kerugian, kerusakan, atau kehilangan keuntungan yang diharapkan akibat timbulnya perjanjian atas pemindahan risiko dari tertanggung kepada penanggung (transfer of risk). Dalam asuransi syariah premi diartikan sebagai kontribusi yaitu berprinsip pada sharing of risk, sehingga dalam menentukan kontribusi didasarkan pada prinsip saling tolong-menolong.

\section{Klaim}

Klaim dalam Kamus Umum Bahasa Indonesia diartikan sebagai tuntutan. Klaim adalah pengajuan hak yang dilakukan oleh tertanggung kepada penanggung untuk mendapatkan haknya berupa pertanggungan atas kerugian berdasarkan perjanjian atau akad yang telah dibuat. (Sudarsono, 2004)

\section{Reasuransi}

Menurut KUHD Pasal 271, reasuransi adalah asuransi dari asuransi/ atau asuransinya asuransi. Transaksi reasuransi merupakan persetujuan yang dilakukan antara dua pihak yang disebut pemberi sesi (ceding company) dan penanggung ulang (reasuradur). (Sudarsono, 2004)

Dalam asuransi syariah disebut retakaful, yaitu proses saling menanggung antara pemberi sesi dengan penanggung ulang dengan proses suka sama suka, dari berbagai risiko dan persyaratan yang ditetapkan dalam akad yang dikenal dengan konsep sharing of risk.

\section{Prinsip Operating Financial System Asuransi Syariah}


Dalam pengelolaan dan penanggungan risiko, asuransi syariah tidak memperbolehakan adanya gharar (ketidakpastian atau spekulasi) dan maisir (perjudian). Dalam investi atau manajemen dana tidak diperkenankan adanya riba (bunga). Ketiga larangan ini, gharar, maisir, dan riba adalah area yang harus dihindari dalam praktik asuransi syariah, dan yang menjadi pembeda utama dengan asuransi konvensional.

Dalam upaya menghindari gharar, pada setiap kontrak asuransi syariah harus dibuat sejelas mungkin dan sepenuhnya terbuka. Keterbukaan itu dapat diterapkan di kedua sisi, yaitu baik pada pokok permasalahan maupun pada ketentuan kontrak, tidak diperbolehkan di dalam kontrak asuransi syariah bila terdapat elemen yang tidak jelas dalam pokok permasalahan dan atau ruang lingkup kontrak itu sendiri. Di dalam kontrak asuransi syariah tidak diperkenankan adanya jual beli ketidakpastian (gharar) antara satu pihak dengan pihak lainnya.

Maisir (perjudian) timbul karena adanya gharar, peserta (tertanggung) mungkin memiliki kepentingan yang dipertanggungjawabkan, tetapi apabila perpindahan risiko (atau pembagian risiko dalam asuransi syariah) berisikan elemen-elemen spekulatif, maka tidak diperkenankan dalam asuransi syariah.

Riba (bunga) sama sekali dilarang di bawah hukum syariah dan di bawah pengaturan asuransi syariah. Untuk menghindari riba, dalam asuransi syariah, kontribusi para peserta dikelola dalam skema pembagian risiko (risk sharing) dan bukan premi, seperti layaknya pada asuransi konvensional. Dalam ketentuan asuransi syariah diberlakukan adanya kontribusi dalam bentuk donasi dewan kondisi atas kompensasi (tabarru). Lebih jauh lagi, sumber dana yang berasal dari kontribusi atau donasi para peserta itu, harus dikelola dan diinvestasikan berdasarkan ketentuan syariah.

Prinsip tolong menolong ini sesuai dengan firman Allah SWT. Yang artinya:

Artinya:“dan tolong-menolonglah kamu dalam (mengerjakan) kebajikan dan takwa, dan jangan tolong-menolong dalam berbuat dosa dan pelanggaran. dan bertakwalah kamu kepada Allah, Sesungguhnya Allah amat berat siksa-Nya." (QS.al-Maidah (5): 2)

Demikian juga pendapat Warkum Sumitro yang memberikan jawaban terhadap kelompok yang mengharamkan asuransi dengan enam alasan, yaitu: a) Asuransi mengandung unsur perjudian yang dilarang dalam Islam; b) Asuransi mengandung unsur ketidakpastian; c) Asuransi mengandung unsur riba yang dilarang dalam Islam; d) Asuransi mengandung unsur eksploitasi 
yang bersifat menekan; e) Asuransi obyek bisnisnya digantungkan pada hidup matinya seseorang, yang berarti mendahului takdir Allah SWT.

\section{ASURANSI TERMASUK JUAL BELI ATAU TUKAR MENUKAR MATA UANG TIDAK SECARA TUNAI}

Lain halnya dengan pendapat dari Majfuk Zuhdi yang membolehkan asuransi syariah dalam prakteknya sekarang ini, termasuk asuransi jiwa, dengan alasan, yaitu: a) Sesuai dengan kaidah hukum Islam. b) Pada prinsipnya pada akad-akad itu boleh, sehingga ada dalil yang melarangnya; c) Sesuai dengan tujuan pokok hukum Islam untuk mencari kemaslahatan dan menolak kerusakan/kerugian; d) Sesuai dengan kaidah hukum Islam; e) Jika ada bahaya yang berhadapan (berat dan ringan), maka didahulukan bahaya yang ringan atau lebih ringan; f) Asuransi tidak sama dengan perjudian, karena asuransi bertujuan mengurangi risiko (reducing of risk) dan bersifat sosial dan membawa maslahah bagi keluarga, sedangkan judi justru menciptakan risiko, tidak sosial, dan bisa membawa malapetaka bagi yang terkait dan keluarga; g) Asuransi sudah memperhitungkan secara tematik untung ruginya bagi perusahaan asuaransi dan bagi para pemegang polisnya, sehingga tidak ada pihak yang dirugikan secara mutlak (berdasarkan ilmu aktuaria); h)Sesuai dengan prinsip hukum Islam, meniadakan kesempitan dan kerusakan dan hidup bergotong royong.

Menurut penulis, disamping asuransi menciptakan kemasalahatan umum, dengan berasuransi dapat mendatangkan rasa aman pada diri sendiri maupun keluarga, karena sudah ada yang menanggung risiko dari bahaya-bahaya yang sewaktu-waktu dapat menimpa diri kita walaupun itu belum diketahui kapan terjadinya. Di sisi lain manusia mempunyai sifat lemah dalam menghadapi kejadian yang akan datang. Sifat lemah tersebut berbentuk ketidaktahuannya terhadap kejadian yang akan menimpa pada dirinya. Sebagaimana firman Allah SWT.

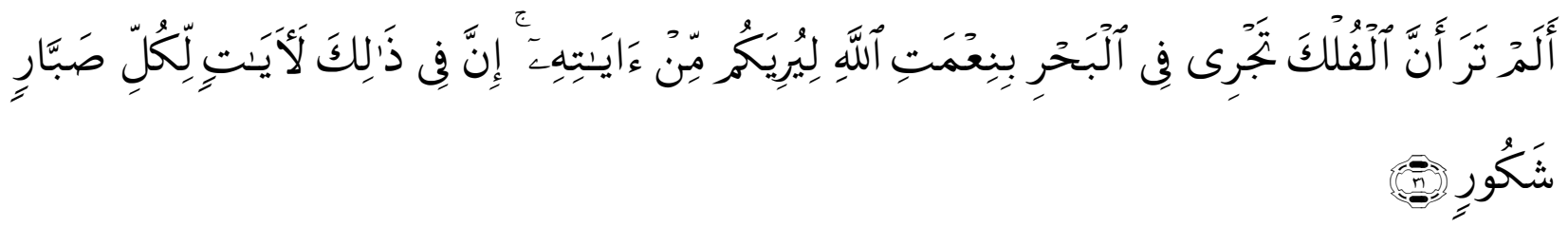

Artinya : tidakkah kamu memperhatikan bahwa Sesungguhnya kapal itu berlayar di laut dengan nikmat Allah, supaya diperlihatkan-Nya kepadamu sebahagian dari tanda-tanda (kekuasaan)-Nya. Sesungguhnya pada yang demikian itu benar-benar terdapat tandatanda bagi semua orang yang sangat sabar lagi banyak bersyukur. al-Lukman (31): 31) 
Ayat diatas menjelaskan bahwasanya manusia itu tidak dapat mengetahui dengan pasti apa yang akan diusahakannya besok atau yang akan diperolehnya, namun demikian mereka diwajibkan berusaha. Adapun caranya adalah menyiapkan bekal (proteksi) untuk kepentingan di masa datang agar segala sesuatu yang bersifat negatif, baik dalam bentuk musibah, kecelakaan, kebakaran ataupun kematian dapat diminimalisir kerugiannya.

Dalam berasuransi syariah, prinsip dasar yang digunakan dalam melaksanakan kegiatan ini harus didasari semangat tolong-menolong (taawun) antara anggota (nasabah).Praktek tolongmonolong merupakan unsur utama pembentuk bisnis asuransi.

Asuransi syariah telah terbebas dari hal-hal yang diharamkan oleh para ulama yaitu bersih dari adanya “maghrib” (maisir, gharar, dan riba). Hal ini dapat dilihat dalam sistem operasional yang dilakukan, dimana dalam mekanisme pengelolaan dananya dapat memisahkan antara rekening dana peserta dengan rekening tabarru. Tujuan dari pemisahan ini untuk menghindarkan adanya pencampuran dana. Sehingga asuransi syariah dapat terhindar dari maisirdan gharar.Adapun masalah riba baik dalam praktik kerugian materi maupun jiwa dapat dieliminir dengan menggunakan instrumen syariah sebagai pengganti sistem riba, misalnya mudharabah, wadiah, wakalah, dan sebagainya.

Pada produk ini peserta berhak menentukan pilihan dana investasi dan persentase alokasinya dari dana investasi. Yaitu diantaranya Allisya Rupiah Fixed Income fund, Allisya Rupiah Balanced Fund, dan Allisya Rupiah Equity Fund. Namun demikian, dana investasi yang diinvestaskan pada pilihan peserta dapat meningkat atau menurun tanpa adanya jaminan dari perusahaan atas batas minimal dan maksimal peningkatan atau penurunan tersebut. Segala risiko yang timbul atas dana investasi terhadap pilihan investasi yang telah dipilih sepenuhnya menjadi tanggung jawab peserta.

Sesuai dengan perundang-undangan yang berlaku atau kebijakan lainnya yang ditetapkan oleh pihak yang berwenang. Perusahaan berhak mengurangi atau memotong dari seluruh assetaset yang berasal dari dana investasi yang telah terkumpul guna membaya ujrah, pajak serta pengeluaran lainnya di luar yang telah ditetapkan dalam polis.

Sistem asuransi syariah adalah sikap taawun yang telah diatur dengan sistem yang sangat rapi, antara sejumlah besar manusia.Semuanya telah siap mengantisipasi suatu peristiwa. Jika sebagian mereka mengalami peristiwa tersebut, maka semuanya saling tolong-menolong dalam menghadapi peristiwa itu dengan sedikit pemberian (derma) yang diberikan oleh setiap individu. 
Dengan pemberian (derma) tersebut, mereka dapat menutupi kerugian-kerugian yang dialami oleh orang yang tertempa peristiwa tersebut.

Sangat jelas bahwa ulama berpendapat asuransi yamg memiliki kandungan syariah diperbolehkan oleh ulama untuk beroperasi dan atau menjalankan bisnis asuransinya, jikalau perusahaan asuransi tetap bersiteguh untuk mempertahankan prinsisp-prinsip yang diatanam oleh ayat-ayat Quran dan sunah rasul. Sedangakan yang tidak diperbolehkan oleh ulama yakni system asuransi yang menggunakan system kinerjanya yang menggunakan cara yang bersifat Konvensional, yakni dengan menggunakan sifat judi atau ghoror.

\section{PENUTUP}

Sebagian para ahli syariah menyamakan sistem asuransi syariah dengan sistem aqilah pada zaman Rasulullah Saw. Takaful dapat didefiniskan dengan al-takmîn, al-ta'âwun atau al-takâful (asuransi bersifat tolong menolong), yang dikelola oleh suatu badan, dan terjadi kesepakatan dari anggota untuk bersama-sama memikul suatu kerugian atau penderitaan yang mungkin terjadi pada anggotanya. Untuk kepentingan itu masing-masing anggota membayar iuran berkala (premi). Dana yang terkumpul akan terus dikembangkan, sehingga hasilnya dapat dipergunakan untuk kepentingan di atas, bukan untuk kepentingan badan pengelola (asuransi syariah).

Pada asuransi syariah seluruh aktivitas kegiatannya diawasi oleh Dewan Pengawas Syariah (DPS) yang merupakan bagian dari Dewan Syariah Nasional (DSN), baik dari segi operasional perusahaan, investasi maupun Sumber Daya Manusia (SDM). Kedudukan DPS dalam Struktur oraganisasi perusahaan setara dengan dewan komisaris. Itulah beberapa hal yang membedakan asuransi syariah dengan asuransi konvensional. Apabila dilihat dari sisi perbedaannya, baik dari sisi ekonomi, kemanuasiaan atau syariahnya, maka sistem asuransi syariah adalah yang terbaik dari seluruh sistem asuransi yang ada.

\section{DAFTAR PUSTAKA}

Amrin, A. (2006). Asuransi Syari'ah. Jakarta: PT Elex Media Komputindo.

Basryin, H. (2001). Dasar-dasar Hukum Asuransi. Bandung: Bandung Perkasa.

H. A. Djazuli, d. (2002). Lembaga Perekonomian Umat Cet. II. Jakarta: PT. Raja Grafindo Persada.

Iqbal, M. (2008). Asuransi Umum Syariah Dalam Praktik. Jakarta: Gema Insani Press. 
Kartiko, A. (2019). KONSEP BAGI HASIL DALAM PERSPEKTIF ISLAM. Indonesian Interdisciplinary Journal of Sharia Economics (IIJSE), 2(1), 1-19. https://doi.org/10.31538/iijse.v1i3.268

Ma'ruf Abdul Jalil. (2008). al-Qur'an as-Sunnah Ash-Shahihah. Jakarta: Pustaka As- Sunnah. Salim, H. A. (2007). Asuransi dan Manajemen Risiko. Jakarta: Raja Grafindo Persada.

Sastrawidjaja, M. S. (1997). Aspek-aspek Hukum Asuransi, dan Surat Berharga. Bandung: PT Alumni.

Sudarsono, H. (2004). Bank dan Lembaga Keuangan Syariah. Yogyakarta: Ekonisia.

Sula, M. S. (2004). Asuransi Syariah (Life And General): Konsep Dan Sistem Operasional. Jakarta: Gema Insani. 